\title{
Create The Plan, Work The Plan: A Look At Why The Independent Business Owner Has Trouble Calling A Franchisee A True Entrepreneur
}

\author{
John Buzza, Monmouth University, USA
}

Joseph B. Mosca, Monmouth University, USA

\begin{abstract}
Our complex and intricate economic system is comprised of many different types and sizes of businesses, ranging from big corporations to small individually owned entities. The genre of business is and can be profoundly complex. Independence can vary from small single person mom and pops to consortiums of multiple partners, silent partners and limited partners. Currently in the United States there are between 600,000 and 800,000 business start-ups a year. Franchising accounts for a significant number of these start-ups, and as an industry is comprised of 1,500 different corporately owned chains and over 750,000 franchised businesses (Quick Franchise Facts, Franchising Industry Statistics). Two terms frequently used interchangeably among the American business society are the terms "franchise owner" and "entrepreneur". There is a popular belief that buying a franchise is an easier route to becoming an entrepreneur than one creating a business on ones own. It is also a common belief that the term "entrepreneur" applies equally to both. Our paper will thoroughly examine the differences between an independent starting his/her own enterprise vs. franchising, where one can purchase an already detailed and complete business plan. Our paper will detail the different percentages of risks to the owner and discuss how and why buying a "system" has many different nuances and is not truly the same as starting a business independently. We will examine the issue of "corporate fraud" and lack of government oversight in franchising and detail the unequal distribution of income as it relates to both independent start-ups and franchise purchases. (As a side note, the Spring 2009 Monmouth University Entrepreneurship class has initiated a partnership with "Cartridge World", an up and coming franchise to open up a retail operation run by the Monmouth University students. It is a true partnership, one in which profits and loses will be shared equally between Monmouth University and Cartridge World. Our research has found that this initiative is the first of its kind between a University and a Franchisor in the country. The macerations of this partnership will initiate many interesting questions and areas for discussion that will profoundly impact the significance of our paper.)
\end{abstract}

Keywords: Business, Franchisee, Franchisor, Entrepreneurship, Risk Taking, Total Independence

\section{INTRODUCTION}

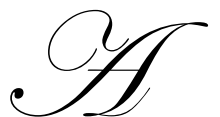

business is defined as "the purchase and sale of goods in an attempt to make a profit" (Dictionary.com). When speaking in general terms, all businesses have similarities no matter how big or small or what industry it specializes in. Every business requires money to create the start-up, as well as maintain it's solvency through daily operations. Risk taking and decision making are a part of the day to day operations of businesses. Specific risks and decisions are different for every business, but are always present. Independents and entrepreneurs alike must realize that one aspect common to all businesses is opportunity opportunity for success but also opportunity for failure.

An independent business owner is someone who takes his idea, his conceptual dream, and transforms that vision into a working reality. Most importantly he is independent in his decision making which will ultimately affect his success or failure. A franchise on the other hand is described as "the right or license granted by a company to an 
individual or group to market its products or services in a specific territory for an allotted period of time" (Dictionary.com). The franchisor is the entity overseeing the actual decision making by the franchisee and in most cases can determine the success or failure of the business initiated by his intrinsic policies. Therefore a case can be made that our future is predetermined by our past. Our personal influence is guided by and limited to a predetermined set of rules and regulations that ultimately influence our success. Both scenarios are truly entrepreneurial but take profoundly different paths. Examining all the components of entrepreneurship is therefore paramount in our comparison of a franchisee vs. an independent start-up.

Entrepreneurship is defined as "creating something new with value by devoting necessary time and effort, assuming the accompanying financial, psychic and social risks and receiving the resulting rewards of monetary and personal satisfaction of independence" (Hisrich,1). There are many recurring reasons that individuals dream of becoming entrepreneurs. The more popular reasons include becoming one's own boss, earning large sums of money, determining vacation time, employing family, retiring young and creating their own hours (Starting \& Operating a New Small Business). According to the National Federation of Independent Business, 39\% are profitable, 30\% break even, and $30 \%$ lose money with $1 \%$ falling in the "unable to determine" category over the lifetime of the business" (Starting \& Operating a New Small Business).

Comparing just the definitions of a franchise owner and entrepreneur, there are two notable differences. Entrepreneurship is the process of crating an entirely new business, whereas a franchise is starting a business from a successful baseline business that already exists. Another difference is that an entrepreneur achieves "the personal satisfaction of independence", whereas this can never truly be achieved by the franchisee (Hisrich, 1). Independence can never be achieved by the franchisee because there is always a franchisor that facilitated creation as well as that franchisor established rules and guidelines that must be followed in order to maintain the integrity of the franchise itself.

A lack of similarities become apparent when analyzing specific activities. Differences between franchises and entrepreneurships are evident in the process of starting the business, operating the business and termination of the business. These differences begin to arise in the initial start-up phase. When opening a franchise, an individual adopts the name, the operating system and support system of that franchise for an average of ten years. The already present support system assumed by the franchisee is a significant benefit to the business. When beginning the franchise, initial training is offered along with an operating manual, advice on management, marketing and personnel decisions. Conversely, the independent entrepreneur has no support system in place other than the one he or she creates. It is suggested that a new entrepreneur seek a support system in the form of paid assistance (consultants) because "it appears that aspiring entrepreneurs are almost doomed to fail unless they receive external help in the form of financial and non-financial support" (McGinty, 2). This assistance is often hard to come by for the independent business owner because of budgetary constraints.

Another significant advantage the franchisee has over the independent is in name adoption and "brand name recognition". When opening up a franchise, hopefully people will recognize the name, equate it to a quality product and help form a customer base without the need for excessive advertising and other very expensive ways of sampling the good or service. Conversely, the independent entrepreneur has to create a name and establish a reputation based on that specific businesses performance. This process takes time and more importantly money that may stretch the independents already limited and strained budget. Social ties previously created by the franchisor are also passed onto the franchisee whereas the entrepreneur must create a social network through casual acquaintances and often family networking.

However the most significant difference between the two is always the bottom line - the level or percentage of success. Although no business is ever guaranteed to become successful, we do play a numbers game. According to a study done by the U.S. Small Business Association, two thirds of small independent businesses last for two years and only $44 \%$ of them survive four years as compared to a $90 \%$ success rate of a franchise business (Dickler).

The two most important reasons for the high success rate of franchises include an existing, already established reputation and an existing support and operating system. Based on a study by the U.S. Banking 
Association, two reasons for business failure include poor business planning and poor financial planning (Khan). Chances of these two reasons causing the failure of a franchised business are significantly decreased because a franchisee is essentially accompanied with and guided by a successful working business plan.

Franchise success often depends on not only establishing name recognition among its clientele but providing consistent appearance, service and performance at all levels of the stores (Kahn). In an attempt to do this, restrictions are established by the franchisor. These restrictions are explained in the Franchise Disclosure Document (FDD), formally known as the Uniform Franchise Offering Circular (UFOC). The FDD contains critical information that a franchisee must know. The document breaks down this information into twenty three sections. This information is certainly not available to the independent. One can look online to garner support documentation, but it can never be as germane to the particular business as the FDD. Items such as biographical outlines of current and past franchisees, any and all litigation, any bankruptcy proceedings, basic product source information and much more are at the fingertips of the franchisee.

Pre-established levels of conformity ensure that a franchise remains consistent in regards to, but not limited to, appearance, available goods and services, advertising, record keeping, signage and employee hours and schedules. The franchisor may control the purchase of raw materials by indentifying specific distributors from which the franchisee is permitted to buy. The site of the franchise must comply with the franchisor and corporate restrictions, whereas the independent entrepreneur has the latitude to choose the site (good or bad) as long as it is lawful. The independent also has the complete autonomy to make all the decisions regarding appearance, purveyors and all decisions associated with the business start-up.

The UFOC document of the Carvel Ice Cream franchise "describes your [franchisee] obligation to buy or lease products or services from us [franchisor] that are approved and according to specifications we [franchisor] issue" (Carvel corporation UFOC 17). This differs from an independent, for example opening up Jesellyn's Ice Cream Stand, who is able to research and look around to obtain the best prices available at the time for all aspects of the business. Carvel's UFOC thoroughly explains what the franchisee is allowed and not allowed to sell. The franchisee "must offer and sell all services, products and programs that we require you to sell that are part of the Carvel System, or that we incorporate into the Carvel System in the future, deviations are not allowed without proper acceptance and payment" (Carvel UFOC, 38). Contrary to the franchise, Jessellyn's Ice Cream Stand is able to create, introduce and/or eliminate any product or modifications desired.

Every business has start-up costs. These costs are readily spelled out in the franchise offering (UFOC) and help the franchisee coordinate his start-up costs right from the beginning of the relationship. These start-up expenditures are a prime example of one area that separates a franchise from an independent business. Let's initially look at the "Franchise Fee" as it is a good starting point for comparison. The industry average for initial franchise fees ranges from $\$ 20,000$ to $\$ 30,000$ (How Much Does a Franchise Cost). The initial investment of a franchise is on average from $\$ 150,000$ to $\$ 200,000$ excluding real estate, whereas research shows "most independent businesses in the U.S. are founded with less that \$50,000 in investment"(Expected Costs of Start-up Ventures, 35). Common to start-up costs for both franchisees and entrepreneurs include but are not limited to grand opening expenses, advertisements, product inventory, insurance permits and licenses pre-expensed salaries and the like.

The initial investment required to open an express store branch of Carvel ranges from $\$ 46,850$ to $\$ 232,860$, excluding real property (Carvel UFOC, 15). Fluctuations in the initial investment required to open an express store branch are due to differences in location, variation in renovation prices as well as variation in all other expenses incurred when opening the express store. The start-up cost for Jessellyn's Ice Cream (or any independent ice cream operation), which will parallel services offered by Carvel express store, range from $\$ 10,000$ to $\$ 75,000$ (Business Idea Center: Ice Cream Stand). The start-up cost differences between these two businesses are mainly due to the established franchise business plan, location requirements, name and operating system required by the Carvel franchise.

A continuing royalty payment is an operational fee that is mandatory for the franchisee and not required for the independent business owner. A royalty fee is "the Franchisor's share of the income derived from customers or clients" (Why Do I Pay a Royalty Fee?). These payments are required whether or not a profit is being earned by the 
franchisee. Royalty payments are paid for the continued use of the franchisor's name. Advertising costs in contrast, are fees that burden both the franchisee and entrepreneur. Although both businesses incur this cost, it is presented in different ways. The franchisee "must contribute a percentage of income to an advertising fund even if the franchisee disagrees with how the funds are used" (A Consumers Guide to Buying a Franchise). The franchisee will most likely need to do additional advertising to support his local business. The independent business owner creates his own plan for advertising and is able to create and allocate advertising resources in any manner they desire, and that could be the problem. Knowing how many dollars to spend and more importantly where to spend those dollars becomes the paradoxal situation that is consistently confronting the independent. Common operational expenses for both franchises and independent entrepreneurships include employee wages, taxes and resupply costs. As both businesses begin to grow and expand, the differences between them become more evident as revealed by each owner's decisions. Restrictions established during the incubator period by the franchisor hold true during the operation of the business as well. When operating the franchise, the franchisee is unable to make any drastic decisions or changes such as introducing new items or a new look for the business. The independent has unlimited control over the business, enabling him to introduce new products or experiment with new appearances without going through the "approval process". Franchisors restrictions on growth and ideas recommended by the franchisee inhibit expansion whereas the independent is able to expand at his own risk and desire. Franchise supplier restrictions remain in effect for the duration of the franchise contract which prevents franchisee deviation. In a few cases franchisors encourage growth by requiring expansion within a started number of years or an offering of certain benefits such as reduced royalty payments. Supplier restrictions could result in higher supply expenditures than would be necessary if deviation to a lower distributor was permissible. These restrictions are intended to maintain consistency of the product being provided. This is different from an entrepreneur who is free to make regular business decisions and changes without restrictions other than government regulation and law.

An additional restriction the franchisor inflicts upon the franchisee is the renewal of the franchise contract. Typically the average franchise contract lasts 15 to 20 years (A Consumer Guide to Buying a Franchise). Acting similar to a lease, the franchisee is committed to that obligation for the specified period of time. Many franchisees look to liquidate after several years, either to going into another venture or just to get out of their present situation. Carvel has a 20 year agreement. The franchisee must apply for renewal after that period (or 2 or 3 years prior), and must meet and of course, adhere to the new guidelines mandated by corporate. This process can take upwards of 30 to 36 months (Issues in Cable Franchising - The Franchise Renewal Process), which can severely inhibit a franchisees flexibility. Franchise termination is another issue that separates the franchisee from the independent. The independent entrepreneur does not have "the corporate Gods" overseeing and controlling their activities or business decisions and therefore does not have to be concerned with termination by someone other than themselves.

A Carvel franchise owner is at the mercy of the franchisor if a default arises. Listed in Carvel's UFOC document are "caused" defined defaults that can be cured and "caused" defined defaults that cannot be cured which may lead to termination of the Carvel franchise. Included in the list are the already mentioned defaults along with other errors that result in termination. Other curable defaults listed by Carvel include mismanagement (a very subjective area in which a franchisor can use its leverage to oust a current franchisee) of the company (location) and default on lease payments (Carvel Corporation UFOC, 40). Although an independent cannot be denied renewal or be terminated by another power, they can be closed due to a multitude of reasons, the most important of which is mismanagement of their business. The Carvel franchise, to its credit, has not had ANY bankruptcies that must be disclosed in the UFOC (Carvel UFOC, 10).

\section{CONCLUSION}

As we can see, the "business agreement" that entitles an individual to adopt a business for a specified period of time, know as a franchise, is very different from that of an independent entrepreneurial venture. Differences are apparent from the earliest stages of each business. Adherence, compliance and lack of complete control become buzzwords that increasingly haunt the franchisee when faced with decisions of consequence. If one wants to buck the trend of working for Corporate America, control and decision making are significant reasons why that mentality exists. But left on our own, without proper guidance, one tends to make decisions either without the proper knowledge or total lack of experience. History shows us that the second independent business a person owns is profoundly more apt to be successful than his first venture. Numbers strongly confirm that inclination. Success 
rates of $90 \%$ are the major reason that most individuals gravitate toward opening a franchise rather than going it alone. Two key factors play a role in the evolution of franchising as compared to independent ownership. The first is that of brand recognition. Consumers immediately know and are familiar with a franchise operation. Only if the franchise is just starting or is completely new to an area might be a reason we could make a case for a level playing field. Therefore most savvy perspective franchisees would not purchase under these circumstances because there is no competitive advantage established by the franchisor. The most significant reason why franchises work in our opinion is the support system offered. There is no substitute for a solid, workable and successful business plan. We cannot place enough value and importance on having a guideline that has proven itself successful. Compliance, while cumbersome at times, is a constant monitoring tool used by franchisors to insure successful continuance of the operation. Independents sometimes can get to creative and move their business in directions directly in conflict to their goals - without ever realizing their motives. When faced with the decision of either purchasing a franchise or going it alone, a franchisor might just have a leg up as he explains to someone on the fence his biggest competitive advantage and value added component - "if it ain't broke, don't fix it".

\section{AUTHOR INFORMATION}

John S. Buzza is currently a Specialist Professor at Monmouth University and Director of The Monmouth University Center for Entrepreneurship, serving full time since 2005. Education has always been a part of Buzza's life, as he has taught at such schools as Farleigh Dickenson University, Essex County College, The Katherine Gibbs School and guest lectured at many other institutions of higher learning throughout the tri-state area. While at FDU and through 2003, Buzza also served on the Board of The Farleigh Dickenson School of Hotel, Restaurant and Tourism Management. Mr. Buzza has served on the Board of The Katherine Gibbs School, working as a liaison between the community and the planned expansion of their campus. Although teaching has always been Mr. Buzza's passion, he has made his mark as an Entrepreneur, being involved as an owner or partner in seven different restaurants and catering facilities, two franchise operations and a consulting business. Buzza spends most of his free time involved in many philanthropic endeavors such as Project Pride, an organization that raises money for underprivileged college-bound students in Newark, and Fresh Start, a New York based organization that mentors incarcerated men in the field of Hospitality at Rikers Island Prison. John Buzza received his Bachelors degree from Monmouth College in 1971 and received his Masters Degree from the University of Phoenix in 2003. John is married to Phyllis for 37 years, resides in Farmingdale New Jersey and has two sons, Matthew and John.

Joseph B. Mosca Associate Professor, Department of Management and Marketing at Monmouth University's Leon Hess Business School, is a member of the graduate faculty. Joe earned his doctorate at New York University, with a focus in business education. Current research interests are the interactive affects of technology and education relating to employees and management. This research is complimented by over twenty five years of upper corporate level administration. Serves as lead professor for: Human Resource Management, Human Relations, Coaching and team Development, Management and Organizational Behavior, and teaches Business Strategy. Has been the recipient of numerous teaching awards including Best Paper recognition awards for research projects.

\section{REFERENCES}

1. “About Entrepreneurship.” National Dialogue on entrepreneurship. 2008. The Public Forum Institute. 29 April 2008 http://www.publicforuminstitute.org/nde/entre/index.htm

2. $\quad$ "Business Idea Center: Ice Cream Stand. "Entrepreneur.com 2008. 1 May 2008 http://www.entrepreneur.com/businessideas/646.html

3. "Carvel Corporation Uniform Franchise Offering Circular." Carvel. 1 April 2006. Free Franchise Docs. 1 May 2008 http://www.freefranchisedocs.com/carvel-UFOC.html

4. "Connecting You to Your Perfect Business...Everywhere: Resources. "Franchise USA. 2006. Franchise USA! Inc. 30 April 2008 http://www.franchiseusainc.com/resources.html

5. Davis, Denise T. "How Much Does a Franchise Cost?” Enzine Articles. 1 May 2008 http://ezinearticles.com

6. Dickler, Jessica. "Six ways to keep your business alive. “CNN Money. 10 January 2007. Time Warner Cable. 30 April 2008 http://money.cnn.com/2007/01/09/smbusiness/tips_avoid_failure/index.htm

7. Dictionary.com. 2008. Lexico Publishing Group, LLC 29 April 2008 http://dictionary.reference.com 
8. "Expected Costs of Startup Ventures." Office of Advocacy. November 2003. Blade Consulting Corporation SBA. 1 May 2008 http://www.sba.gov

9. Hisrich, PhD, Robert D., Michael P. Peters, PhD and Dean A. Shepherd, PhD. Entrepreneurship. 6 ed. New York: McGraw-Hill Irwin, 2005. http://entrepreneur.com

10. Hollowell, Ken. "Item by Item Description of the UFOC." National Franchise Services. National Food Service Advisors. 1 May 2008 http://www.nfsaconsultants.com/articles.html

11. InvestorWords.com 2008. WebFinance, Inc. 30 April 2008 http://investorwords.com/2833/liquidate.html

12. $\quad$ "Issues in Cable Franchising - The Franchise Renewal Process." New York State Public Service Commission. 2007 New York State Department of Public Service. 30 April 2008 http://www.dps.state.ny.us/rnwlproc2.htm

13. Khan, Sharif. "The Chief Cause of Business Failure and Success." National Business Association. 2005. 30. April $2008 \mathrm{http}: / /$ nationalbusiness.org/NBA WEB/Newsletter2005/2029.htm

14. McGinty, Robert L. "Free advisory services create an entrepreneurial opportunity." 15.11998 55-63. 3 March 2008 http://emeraldinsight.com/Insight/viewContentItem.do?contentType=Article\&contentId=856278

15. Merriam Webster Online. 2008. Merriam-Webster, Incorporated. 30 April 2008 http://merriamwebster.com/dictionary/bankrupt

16. "Quick Franchise Facts, Franchising Industry Statistics." 20081. http://azfranchises.com/franchisefacts.htm

17. Redding, Melissa. "Franchises vs. Independent Businesses." Franchise Loop. April 2008 http://franchiseloop.com/news/?p=26

18. "Starting \& Operating a New Small Business." Business 188-Entrepreneurship - Facts \& Figures. 2008. Cabrillo. 29 April 2008 http://www.cabrillo.edu/ damfrosini/188Web/classessions/entrepreneur.htm

19. "Why Do I Pay A Royalty Fee?" Franchise Gator. 2008. 1 May 2008 http://www.franchisegator.com/articles/royalty_article.html 